\title{
Organizational Learning Capacity as sustainable Competitive Advantage: Role of Leader's Emotional Intelligence and Resistance to Change on Organizational Learning Capacity
}

\begin{abstract}
Dr. Muhammad Jawad ${ }^{a^{*}}$, Dr. Saqib Anwar Siddiqui ${ }^{\mathrm{b}}$, Dr. Munazza Naz ${ }^{\mathrm{c}}$, Mr. Nauman Waheed ${ }^{\mathrm{d}}$, Dr. Sohail Rizan ${ }^{\mathrm{e}}$, Mr. Muhammad Aftab Shamsif, aPost Doc, Ph.D, Department of Commerce, Fatima Jinnah Women University, Pakistan. *Corresponding Author, ${ }^{b}$ Department of Leadership and Management Studies, National Defence University, Islamabad, Pakistan, ${ }^{\text {cPost }}$ Doc, Ph.D, Department of Mathematics, Fatima Jinnah Women University, Pakistan. ${ }^{\mathrm{d}, \mathrm{e}}$ Department of Commerce, Fatima Jinnah Women University, Pakistan. fUniversity Institute of Management Sciences, PMAS-Arid Agriculture University, Rawalpindi, Pakistan. Email: a*muhammad_jawad85@yahoo.com, ${ }^{\mathrm{b}_{\mathrm{s}}}$ aqib.phd@gmail.com cmunazzanaz@fjwu.edu.pk,_dnauman_acc@yahoo.co.uk, esohaildotrizwan@gmail.com, ${ }^{\mathrm{f}} \mathrm{chaftabshamsi@gmail.com}$
\end{abstract}

This research study is based on the investigation and validation of Organizational Learning Capacity with regards to leaders in educational sector as source of Competitive Advantage to the Higher Education Institutions and testing the impact of leader's Emotional Intelligence (EI) and Resistance to Change to enhance Organizational Learning Capacity (OLC). This study can be the hallmark for the HEI's for gaining competitive advantage through their human capital.The results shows that EI has significant contribution towards the OLC and when measured together with the trait of resistance to change the results significantly transformed which suggest that RTC negatively and significantly affect the relationship between EI and OLC therefore, to control and reduce the aspect of resistance to change by enhancing and investing in the trait of Emotional Intelligence of the individuals and leaders is suggested to gain the benefits of OLC to become superior in the industry.

Key words: Competitive Advantage; Leadership Strategy; Emotional Intelligence; Organizational Learning Capacity. 


\section{Introduction:}

Gaining 'Competitive Advantage' is among one of the challenging facets for the organizations (Paul, 2017), whether, it is associatedto a product, process, people or any other such aspect, that distinguishes the organization to perform differently from the industry. Many researchers referred the term of "Competitive advantage" as a "centrepiece of the Strategic Management Dialogue", that elucidates various levels of organizational portability (Porter, 1980; Barney 1991). De Geus(1988) states that, the ability to learn faster than the competitors may be the only sustainable competitive advantage. According to Saeidipour, B. et.al., (2012) the basic entity of knowledge generation is the "Individual" itself wherein knowledge resides as a human capital. The victory of organization and workplace environment entirely depends on the effectiveutilization of human conscious intellectual abilities which essentiallyshouldered by supervisors, managers and stakeholders, as a challenge to settle the organizational affairs (Kazemi et al., 2013).

\subsection{Organizational Learning Capacity (OLC):}

Organizational Learning Capacity (OLC) plays a pivotal role in the organizations to maintain competitiveness in the market (Aydin, and Ceylan, 2009). It is categorically recognized and emphasized in the literature that the development of OLC is a fundamental factor for the achievement of long-term competitive advantages (Ologbo\&Chukwuekezie, 2013). Dimovshki (1994) substantiated the significanceof organizational learning with respect to the overall enhancement and improving the performance of the organization and to gain competitive advantage in financial and human development in the domain of strategic management.

Organizational Learning Capacity (OLC)' is referred to as the perimeter of an association/ firm to assemble the capabilities and capacities in the workers to obtain new data, and to change over that data into specific beneficial information (Aydin and Ceylan, 2009b). It is a cumulative process of 'System orientation' i.e. creating association between internal and external systems of the organization that makes a common understanding that enables the firm to be seen as a system.,' Learning orientation' i.e. creating and augmenting the prevalent internal atmosphere and culture of learning in the organization for strong commitment to learning 'Knowledge acquisition and utilization orientation' i.e. the capacity to act ahead of changes, that is to be proactive rather than reactive and making an accentuation on investigation of new data and information and 'Information sharing and dissemination orientation' i.e. open channels of communication, liberty of employees, encourage and promote professional development in them (Çömlek et al., 2012). In this aspect, OLC goes beyond the basic rules of organizational learning. It builds and transforms the behaviour and attitudes of employees for assimilating and disseminating new knowledge (Teo et al., 2006). At organizational level it establishes the general auxiliary changes that fortify the organization to accomplish enhanced outcomes, guarantees flexibility to change, 
development through advancement and output-wise productive employees conceiving OLC as commitment to the companies to remain focus and abreast on their perceptions complete positively in the worldwide activities (Kanwal et al., 2017).

A number of organizational learning techniques have been enunciated by Nevis et, al., (1995) to manage the existing framework, focusing on the basic variables and changing in the learning atmosphere. Introducing the framework of learning, sharing data with the organizational people, gaining information, and subsequently reaching a consensus, are the main focused precincts of the advanced learning in hierarchical environs (Teo and Wang, 2005). Thus, Organizational Learning Capacity is accepted as a factor that provide competitive advantage (Çömlek, Kitapçı et al., 2012).

\subsection{Emotional Intelligence (EI):}

Emotional Intelligence (EI) is characterized, as an ability of a person to perceive and distinguish the feelings, make and recover feelings thus helps in accomplishing the contemplating stature (Mayer and Salovey 1997). Goleman (1995) characterizes Emotional Intelligence as a fitness of a person that enumerate his or her sentimental physiognomiesin term of feelings, desires, personal qualities, strength and weaknesses, objectives, ambitions, beliefs etc, and to trace the identical traitsin other individuals working around him in similar situations. Consequently, Emotional Intelligence refers to an arrangement of nonintellectual capacities, abilities, and aptitudes that enable the person to prevail with regards to taking care of and manage the natural requests and weights (Altındağ\&Kösedağ1, 2015). IQ isn't the last or even the most imperative indicator of effective occupation execution(Cherniss, 2001).

Emotional intelligence is the fundamental regulator of emotional talent or passionate ability, which decides how we could utilize our aptitudes most ideally utilizing level-headed legitimate course. 'Management of emotions' is the capacity of the individual for directing his own feelings, and that of others to advance forward passionately for effective improvement (Ramy, Akbar \&Jamshidy, 2014).

To depict emotional intelligence, it is initially critical to characterize the ideas which it consolidates, basically what is definitely implied by both "Emotional" and "Intelligence" exclusively. 'Emotions' the intelligence expressions expressed within the construct of EI, have been defined as a brief, composed arrangement of reactions (counting mental changes, expressive practices, activity propensities, and subjective encounters) that enhance how people encounter difficulties and endeavour to open the doors which obstruct their opportunities that they experience (Lazarus 1991). American Psychological Association's task force defines intelligence as "capacity to comprehend complex thoughts, to adjust successfully to nature, to gain as a matter of fact, to participate in different types of thinking, to conquer hindrances by taking idea" (Neisser et al. 1996). Impartially, emotions and 
intelligence have been acknowledged as the begetters of numerous fields of science and for cogent reasons these compact definitions precisely portrays the feelings and knowledge (Boyatzis\&Saatcioglu, 2008).

\subsection{Resistance To Change (RTC):}

The tendency to resist changes is generally viewed negatively; nonetheless Oreg (2018) study supports a comparative unbiased assessment of dispositional resistance to change, acknowledging its potential benefits for performing routine tasks, side by side its detrimental effects with respect to performance on non-routine tasks and other exigencies.

'Change' is a situation that interrupts normal patterns of organization and calls for participants to introduce new patterns, involving an inter-play of thoughtful land emergent highly ambiguous processes (Mintzberg\& Waters, 1985). In these circumstances, both 'change-agents' and change recipientsget involved in anintellectual formation of change process referred as 'sense-making'. The change-agents focus on the accomplishment of the change whereas, change-recipients speculate for the effect of change on them. The vigorous process of sense-making embraces the interaction among the peers for sense-attribution, information-seeking and associated rejoinders for apprehending behaviours and communications of on-going events, figuring out for common values, and then acting on the resulting elucidation (Thomas, Clark, \&Gioia, 1993).

'Resistance' is the interpretation assigned by change-agents to the behaviours and communications of change-recipients or these interpretations are either self-serving or selffulfilling. Literature on 'Change'seems to de-limit the viewpoint of the concept of resistance wherein, the change-agents are only considered for performing the things in a right direction while change-recipients oppose and contest forthe hindrances and extra burdens that may result due to the change (Ford, Ford, D'Amelio, 2008).

'Resistance to Change' is the individual's dispositional inclination to resist change, (Oreg 2003) and is a multidimensional disposition that comprises behavioural, cognitive and effective components. One factor that appears to be constant in organizations today is the change. Indeed, the organization's ability to deal the with change provides a competitive advantage (Jordan 2004).

\subsection{Higher Education Sector of Pakistan:}

Higher educational institutes are considered as the backbone of any society in providing the qualified, skilled and competent human resource (Mir \&Abbasi, 2012). One of the primary objectives of training and graduate management education is to prepare people to perform as outstanding managers, leaders, and professionals (Boyatzis\&Saatcioglu, 2008). The factor local growth \& globalization has influenced the every segment of every industry, and 
correspondingly inspired the education sector. It is often presented as a strategic effort exerting by organizations to acknowledge the world as a single market to strengthen their business activities (Tallman \&Fladmoe-lindquist, 2002).

Nowadays education is characteristically becoming a more versatile phenomenon and a service enterprise (Constantinescu \&Alexandrache, 2014), leaving behind the traditional mode of learning i.e. class-based teaching methodology. The technological advancement has made the education more accessible to every individual as a challenging venture for the teaching staff and administrative authorities of the institutions. Quality assessment in higher education is both a national and a global concern for academic leaders (O'Brien, 2009).

Pakistan is a developing country where the education sector is facing many challenges in terms of quality human resource (Nawab\&Bhatti, 2011). In Pakistan, higher education refers to education above grade 12, which generally corresponds to the age bracket of 17 to 23 years. The role of Universities is very important in setting the educational atmosphere in the society and social growth and for the purpose it is a dire need to renovate the systems and conditions and to promote the satisfaction of the workforce of the educational organizations in Pakistan (Khan, Nawaz \& Khan, 2013). The educational performers are the most important in the process of change, because beside the position they adopt towards change, of a great importance are the beliefs, attitudes, ideologies and behaviour of the performers involved in it (Constantinescu \&Alexandrache, 2014). Thus, the capacity to learn in the challenging environment of rapid changes in the curricula and teaching methodology remains the stimulating aspect for educational leaders as well as individual themselves associated with this industry.

\section{Literature Review:}

\subsection{Emotional Intelligence (EI) \& Organizational Learning Capacity (OLC)}

Within the organizational learning literature, learning is often presented in two ways: as a process and as an outcome (Ghosh, et. al., 2012). Kazemi et al., (2013) have identified the noteworthyassociationbetween the traits emotional intelligence i.e. self-awareness, selfregulation, social- awareness and social- skills with organizational learning. Post analysis, evidence suggested EI was significantly and positively related with team psychological safety and team learning (Ghosh, et. al., 2012).

Employee behaviour mostly effected by the cause of emotional intelligence in an individual leads toward the factor of organizational learning (Kazemi et al., 2013). Scott-Ladd and Chan (2004) argued that if employees are more emotionally intelligent they have more impact on the overall effectiveness on the organizational learning specifically in defining the executional and operational limits \&plays participating role in decision making. 
Mayer and Salovey (1997) suggested four components for emotional intelligence based on the individual's emotional intellect, i.e. general intelligence, knowledge, perception, and regulation. On the other hand, the framework of organizational learning defined by Senge(2006) includes five features i.e. personal mastery, team learning, systematic thinking,mental models and shared vision. High levels of emotional intelligence are supposed to contribute substantially to higher performance outcomes and inter-group relations, and are a prerequisite for organizational learning.

The concept is actually derived from social intelligence introduced back in early nineties(Johnson and Indvik, 1999), The term Emotional Intelligence though was made popular by Goleman $(1995,1998)$; which refers to the ability of an individual to understand and relate to people (Johnson and Indvik, 1999). On the other hand the term 'Abstract Intelligence' is also describedin the literature of intelligence, which is linked with the ability of an individual to understand and manipulate symbols. Thus, Emotional intelligence is described as the individual's capability to judge and sense the reality in an accurate mannerfor the purpose to understand, regulate and adapt his/ her own emotional responses and accordingly respond to others. The individuals who understand their own emotions can more accurately identify their responses and so change if need be.

Further, the intellectual use of emotions means individuals' cognitive decisions are more acute, so they are better able to assimilate information, make judgements or be creative and solve problems. This suggests emotionally intelligent people are more self-aware regarding their strengths and limitations, and because of this they are claimed to be more confident, optimistic, flexible, innovative and comfortable with new ideas (Bellack, 1999; Goleman, 1995, 1998; Mayer and Salovey, 1997). Clearly, such employees offer advantages to contemporary organizations wanting to gain competitive advantage through adaptability, rapid response and change innovation. Management theorists and researchers recognize that organizational ability to learn, facilitates organization-wide improvements and change adeptness. Such adaptability enhances the competitive position through improvements in efficiency, productivity and innovation (Solomon, 1994).

Nonetheless, the general conclusion is that organizational learning is a set of activities designed for organizational improvement in processes initiated by the learning organization and one such strategy is the clearly defined guidelines of participation in decision-making.

While keeping in context the outcomes that any organisation can basket by embedding emotional intelligence does have clear signs of positivity. While a segment of analytics entails merely by uplifting emotional intelligence level is enough to bring change in organisational development \& learning capacity, also to play their role in the scheme to bring change. The focal point should need to be \& not to be diverted from "Organisational Gains" at any time, while taking the process of change further forward as implementing and completing it rapidly and effectively could define the edge over the rest of competitor in 
market. (De Geus, 1988). OL targets to enhance innovation via flex individual reaction as set of options are available to take individual response and judgment as a result organizations response becomes on time and proactive (Solomon, 1994).

Emotionally intelligent professionalslikes to be a part of centre stage for the sole reason of being harmonious and go well together trait so does creates the window of opportunity to get the mega goal achievement (Gardner and Stough, 2002), In the same way they consider themselves as one who owns the organisational objectives in line with the individual appraisal that one receive being a part of team.

In contrast to this emotionally intelligent persons are good receiver when eliminated from any task or team or given specific or partial insertion in such cases, for as Schutte et al. (2001) highlights emotionally intelligent professionals more attracted towards the outcomes that benefits everyone as team. With respect to indulgence of high level of volatility or instability in business culture and surroundings the analysts consider EL as blessing to cope the issues of growth management. The key expected rewards came in the shape of organisational \& professional loyalty, team work, and personal and organisational growth based on performance.

Canadian study draws the conclusion in context of high ranking managers proactive and practical leadership trait, is being triggered by embracing the OL practices. In parallel to this the organisational prime of life time further enhances the OL. So the EI \& OL are key factors which one can't ignore at any time of the current business scenario, to consider for the new born organisations as they have to face the organisations already in the ring for the long time (Scott-Ladd \& Chan, 2004).

\subsection{Emotional Intelligence (EI) And Resistance To Change (RTC)}

There's an increasing trend of researching the character of EI in context of RTC. Change is a notoriously opaque notion. Some of these concepts went through a fashion cycle; others have endured in the stock of knowledge of how to run a profitable business. The theory of RTC as person's response offers avenue for potential study related to other personality traits such as EI(Di Fabio, Bernaud, \&Loarer, 2014).Vakola et al., (2004) did the empirical research over part of EI and individual traits in context of short-term behaviours towards the organisational change that resulted in a new dimension of analysing OC via individual frame. The outcomes of thisresearch creates the opportunity of existence with regards to have a link between EI and attitudes (short term behaviours) towards OC, with the core stance of utilizing emotions to execute result oriented policies \& strategies as part of solution.

Level of expertise while utilising the emotions to bring change are of key importance for achievement of desirer or expected goals in the whole scheme (Di Fabio, Bernaud, \&Loarer, 2014). Leader's obligation can't be undermined while organisation is set to roll the internal 
strategic change initiative.In this regard RTC mainly deals with the emotional response to change and observing, focusing \& studying the subordinates or peers emotions construct the EI of the leader, is something of great concern for modern and emerging organisations (Voola, Carlson et al. 2004). The Literature recommends the precedent of competitive edge goes to those organisations who map, execute and control change as policy (Mayo, 2002). As RTC is primarily an emotional response, which sometimes considered as rational and at times irrational (Werther, 2003), modern-day business leaders needs to engage their power or business circle cognitively as well emotionally in order to get done with the cost effective strategic change, this cannot be achieved without the characteristics of EI implanted in leader (Voola, Carlson et al. 2004). Judgeet., al, (1999)linked several other traits to a work-oriented concept of coping with change.

It was to gauged with 12-article range to determine the employees consideration, primarily with respect to how necessary is to bring change in organisation? Secondly to evaluate the level of perception to manage change? Thirdly by considering employees as pioneers in bringing change(Oreg 2003). It was the situational experience perspective which earlier and majority of the authors considered while defining RTC (Coch\& French, 1948; Zander, 1950). The recent shift took place to assess RTC from individual differentiation optics(Oreg 2003),He identified 6 sources that motivate an individual to resist from the change. Those six sources are(a) Reluctance To Lose Control, i.e. Individuals may resist changes because they feel that control over their life situation is taken away from them with changes that are imposed on them rather than being self-initiated (b) Cognitive Rigidity, i.e. Individuals are characterized by rigidity and closed-mindedness and therefore might be less willing and able to adjust to new situations (c) Lack Of Psychological Resilience, i.e. less resilient individuals are more reluctant to make changes because to do so is to admit that past practices were faulty, and therefore change entails a loss of face (d) Intolerance To The Adjustment Period Involved In Change, i.e. People resists change because it often involves more work in the short term(e) Preference For Low Levels Of Stimulation And Novelty, i.e. People who resist change would exhibit a weaker need for novelty (f) Reluctance To Give Up Old Habits, i.e. When individuals encounter new stimuli, familiar responses may be incompatible with the situation, thus producing stress, which then becomes associated with the new stimulus.

EI has raisedas a mountingquarter of research in OC domain (Doorewaard and Benschop, 2003) as well in leadership study (Zhou and George, 2003). There's quite a consciences occur with regards to strategic perspective as limited understanding exists in explanation, as by which means EI can be further groomed in the long run benefit to be in a position to achieve the competitive edge in organisation Di Fabio (2011) used the Emotional Intelligence Scale (EIS; Schutte et al., 1998) to study the relationship between the three factors of the Resistance to Change Scale (RCS; Oreg, 2003) (i.e., Routine Seeking, Emotional Reaction to Imposed Change, and Cognitive Rigidity) among Italian university students (306 and 213 university students, respectively). Di Fabio's (2011) results revealed that, for Italian students, emotional intelligence is related to resistance to change at an individual level, in particular 
concerning routine seeking and emotional reaction to imposed change. The study of the relationship between resistance to change and emotional intelligence may be promising (Di Fabio, 2011; Malik \&Masood, 2015) because emotional intelligence is a variable that can be developed or increased through specific training (Malik \&Masood, 2015).

Fatima (2002) described pertinentsteps of changes in Pakistani organisations, focusing the rationale and emotion as key trait within the change agent, in a way that further elaborates as the RTC solely emerged from absolute personal interests not from organisational or professional interest. In this scenario all needed is to trigger the personal interest picture of the story thus it will fuel up the organisational \& professional interest, but need to have work done well before tine with regards to the alignment of personal \& professional interest in the context of current organisational requirements.

\subsection{Resistance to Change (RTC)\& Organizational Learning Capacity (OLC)}

Resistance in organizations usually emerges in two opposite directions, either for the purpose of resisting existing structures or to resisting change initiatives (Mullings, 1999). In order to implement the value added \& thriving change schemes it's a must to create the sense of preparation, urgency and of doing something new \& unique among the implementing staff from top to bottom as advocated by the literature abundantly (Rafferty and Simon, 2006). Resisting change either at social level of on technical grounds is another dynamics, as people do resist more often on social grounds rather than on technical grounds (though they are not separate in practice). Any change implementation scheme that pay no attention to psychological resistance towards change, tend to fail regardless of the uniqueness of the presented ideas via that scheme (Schein 1986). Since learning considered as permanent transformation in behaviour, therefore there seems to be a strong relationship between organizational learning capacity and resistance to change.

To re-conceptualize resistance we have to consider it as workable fact in first instance rather than as burden or resource wastage, thus that's the only way to produce positive impact on organisational productivity. Along with this there's a segment of researchers who recommends that we shift our focus on overcoming resistance rather than addressing the root cause of resistance ieinfact should be considered as delta of resistance and should needed the due cure for the sole reason to fix the issues arising in the implementation process (Lawrence, 1954).

Jost and Bauer (2003) takes the design to another level of elevation by adding the symbolic painprospective of resistance, thus suggesting a shift of focus from cause to effect in context of RTC. By this pain symbol in human body is as equal as resistance in organisational body as s sign of discomfort as well something is not good and need to pay attention \& treatment from further damage in either human or organisational body does in the human body, considered as feedback and control dimension while implementing change (Jost\& Bauer, 
2003). Now, how the leaders or implementing supervisor does came to know that dosage of change needed either as pioneer or already in the execution phase by monitoring the resistance, whenever the resistance occur it's a signal to take the change implementation steps to a new level.Apart from the cause of resistance, it primarilydenotes the presence of stress and clash of interests in the current state, which is a clear signal that situation is not perfect and needed to be probed a improvement measures should be taken.Imagine the two approaches in this regards one organisation ignore the resistance came out from stress or clash of interest, while the other take the re-directive measures from identification to rectification measures (Dent \& Goldberg, 1999). Without any doubt the later one would be in better position in the long run as it passed through the phase of identification \& rectification process, which becomes as bench mark for the future issues to come and they would be well equipped to cope the resistance. While the issues will remain on surface for the former organisation either become more complicated or at the same level, they would tend to be a burden if not as a threat for organisation to solve, thus without solution to internal issues any organisation cannot be in a position to solve the external issues so does lack innovation. Hence while implementing Jost and Bauer (2003)'s pain symbolic theory, it can be considered as rational in case of pain, stress or resistance, the institution perceptivetendency is to reach ways parallel to those (cycle of events)recommendedby Wall (1979). In this scenario the RTC does have two folds first it's a reflective media secondly it's a medium which is a source of prime reflection. As a result, resistance can be above allhelpful in inspiring a precise learning, introspective learning in any organization.

\section{Theoretical Framework}

\subsection{Independent Variable:}

Success or collapse factor while implementing any change scheme mostly directly proportion to the emotional perception frame of employee (Malik \&Masood, 2015). Vakola et al. (2004) tossed the factor,i.e EI can considerablyforecast the employeesattitude in the direction ofchange and learning capacity. As a result in this research selected EI an independent variable, measured using 33 items scale developed by Schutte\& others in 1998, based on the theoretical model of Mayer\&Solevy in 1990.

\subsection{ModeratingAnd Mediating Variable}

Resistance to Change (RTC) can be expected to moderate\& mediate the connection among EI \& OLC Capacity.As mentioned in research of Beal IIIet. al (2013) resistance to change moderates the relationship of psychological capital and organizational citizenship behaviour Resistance to Change has been measured using 17 item scale developed by (Oreg 2003). The scale was designed to measure an individual's dispositional inclination to resist changes i.e. an individual's tendency to resist or avoid making changes, to devalue change generally, and to find change aversive across diverse contexts and types of change. The scale is used to 
account for the individual-difference component of resistance to change and to predict reactions to specific change.

\subsection{Dependent Variable}

Organizational Learning Capacity has been measured using 16- item "Organizational Learning Capacity Scale (OLSC)" developed by Kimberly D. Bess, Douglas D. Perkins and Diana L. Mccown(Bess, Perkins et al. 2011) adopted and shortened from Watkins and Marsick's dimensions of Learning Organizations Questionnaire. The scale has been successfully tested for the reliability and consistency to measure the following six dimensions of OL, (1) internal organizational system alignment (3 items), (2) external organizational system alignment ( 3 items) and promoting the culture of learning (3 items) (3) emphasis on exploration and information, (4) open communication (2 items), (5) staff empowerment (2 items), (6) support for professional development 3 items).

\section{Methodology}

\subsection{Population and sampling}

Random Sample of 367 faculty and staff from 22 local Universities was drawn on the total strength of 7890 as per the Table 10.3 of Uma Sekaran Book page 295 (Sekaran, 2003). Sampling was based on the "snowball" method. Online questionnaire on Google Forms was floated through the Heads of the Institutions/ Vice Chancellors, recognized by the Higher Education Commission of Pakistan, amongst which 367 valid responses were considered to validate this study.

\subsection{Survey Instrument}

The questionnaire was developed from the adopted questionnaire of previous researches and was pre-tested by administrating it to a sample of twenty five Faculty members and Administration staff of the HEIs to check its construct validity. The construct validity was tested using cronbach's alpha test which resulted in a value above 0.70. Emotional Intelligence was measured using 33 items scale developed by Schutte\& others in 1998. Organizational Learning Capacity was measured using 16- item "Organizational Learning Capacity Scale (OLSC)" developed by Kimberly D. Bess, Douglas D. Perkins and Diana L. Mccown(Bess, Perkins et al. 2011) adopted and shortened from Watkins and Marsick's dimensions of Learning Organizations Questionnaire.

\subsection{Data Collection}

The focus sample constitutes in current research is limited to theworkforce\&faculty members encompassing Higher Education Sector of Pakistan, consist of 22 public and private sector 
universities located in Islamabad, Rawalpindi, Wah, Taxila, Haripur and Abbottabad. As per Higher Education Commission of Pakistan's statistics, total fulltime faculty members in the universities under study was 7890 (source: http://www.hec.gov.pk/english/ universities/ Pages/Full-time-Faculty.aspx).

\section{Analysis}

\subsection{Summary of Measures}

\section{Constructs}

Emotional Intelligence

Resistance to Change

Organizational Learning Capacity
Items

33

16 Bess, K.D., Perkins D.D \&McCown D.L (2011)

Author(s)

Schutte et al. (1998)

ShaulOreg (2003)
The instruments for the constructs of the research study were drawn from the previous research. Emotional Intelligence instrument was adopted from authors Schutte et al.'s (1998) and it is consisting of 33 items. Moreover, Resistance to Change instrument was adopted from author ShaulOreg (2003) and it is consisting of 17 items. Furthermore, Organizational Learning Capacity instrument was adopted from authors Bess, K.D., Perkins D.D \&McCown D.L (2011) consisting of 16 items. Targeted sample responses were collected on likert scale (5 point from strongly disagree to strongly agree). 
International Journal of Innovation, Creativity and Change. www.ijicc.net

Volume 15, Issue 6, 2021

\subsection{Demographic Variables Profile}

\begin{tabular}{|c|c|c|c|}
\hline Demographic & Category & Frequency & Percentage \\
\hline \multirow{2}{*}{ Gender } & Male & 218 & 59.40 \\
\hline & Female & 149 & 40.60 \\
\hline \multirow{8}{*}{ Age } & 30 Years or below & 58 & 15.80 \\
\hline & $31-35$ Years & 73 & 19.89 \\
\hline & $36-40$ Years & 81 & 22.07 \\
\hline & $41-45$ Years & 55 & 14.98 \\
\hline & 46 - 50 Years & 11 & 2.99 \\
\hline & $51-55$ Years & 51 & 13.90 \\
\hline & $56-60$ Years & 30 & 8.17 \\
\hline & 60 Years and above & 8 & 2.17 \\
\hline \multirow{2}{*}{ Sector } & Public & 253 & 68.94 \\
\hline & Private & 114 & 31.06 \\
\hline \multirow{5}{*}{$\begin{array}{c}\text { Professional } \\
\text { Experience }\end{array}$} & 5 Years or below & 49 & 13.35 \\
\hline & $6-10$ Years & 152 & 41.42 \\
\hline & $11-15$ Years & 78 & 21.25 \\
\hline & $16-20$ Years & 71 & 19.35 \\
\hline & 21 Years and Above & 17 & 4.63 \\
\hline
\end{tabular}

As we early discuss that this research study was implemented on higher educational institutions of Pakistan. After distribution the questionnaire, we get 392 responses from which 367 responses was completed in all respects and proceed for analysis.

Among 367 valid responses, 218 responses were received from male which were 59.40 percent of the accepted sample and 149 responses from female which were 40.60 percent of the accepted sample.

Furthermore, if we discuss about age group of responses, 58 responses were received from 30 years and below which were 15.80 of the accepted sample, 73 responses from 31 years to 35 years which were 19.89 of the accepted sample, 81 responses from 36 years to 40 years which were 22.07 of the accepted sample, 55 responses from 41 years to 45 years which were 14.98 of the accepted sample. Moreover, 11 responses were received from 46 years to 50 years which were 2.99 of the accepted sample, 51 responses from 51 years to 55 years which were 13.9 of the accepted sample, 30 responses from 56 years to 60 years which were 8.17 of the 
accepted sample and 8 responses were received from 60 years and above age group which were 2.17 of the accepted sample. In addition to above, if we discuss about higher educational institute sector, we get 253 responses from public sector institutes which were 68.94of the accepted sample, along with this we get 114 responses from private sector institutes which were 31.06 of the accepted sample.

Afterwards, we discuss the professional experiences of our accepted sample, we get 49 responses from having 5 years and less professional experiences in their field which were 13.35of the accepted sample. Furthermore, we get 152 responses from having 6 to 10 years of professional experiences which were 41.42 of the accepted sample, 78 responses having 11 to 15 years of professional experiences which were $21.25 \%$ of the accepted sample, 71 responses from having 16 to 20 years of professional experiences which were 19.35of the accepted sample and 17 responses from having 20 years and above professional experiences which were 4.63 of the accepted sample.

\subsection{Descriptive Statistics}

\begin{tabular}{cccc} 
& EI & RTC & OLC \\
\hline Mean & 3.136845 & 2.928325 & 3.222871 \\
Median & 3.090909 & 2.882353 & 3.250000 \\
Maximum & 4.878788 & 4.352941 & 5.000000 \\
Minimum & 2.121212 & 1.647059 & 1.250000 \\
Std. Dev. & 0.352473 & 0.398783 & 0.573227 \\
Skewness & 0.623851 & 0.092329 & -0.236290 \\
Kurtosis & 1.100149 & 1.161880 & 1.990782 \\
\hline
\end{tabular}

After Demographic Analysis, we will proceed for descriptive statistic to define basic analysis. In this research, while discussing about emotional intelligence, the value of mean is 3.1368 with the standard deviation of 0.3524 which mean that the responses have less deviation. Furthermore, data was normally distributed as skewness and kurtosis values lies between -2 and 2. Furthermore, when we check the descriptive analysis of Resistance to Change, we find that the mean value is 2.9283 and the standard deviation 0.3987 . The data analysis describes less fluctuations in responses. Moreover, the skewness and kurtosis reflect normal distribution in collected data. Afterwards, while analysis the Organizational Learning Capacity, we find the mean value is 3.2228 and the standard deviation is 0.5732 which is higher than other variables, but the value is not much volatile. In addition, the data is normally distributive identified through skewness and kurtosis. 
International Journal of Innovation, Creativity and Change. www.ijicc.net

Volume 15, Issue 6, 2021

\subsection{Discriminant Validity-Fornell-Larcker Criterion and Correlation Analysis}

\begin{tabular}{lccc} 
& $\begin{array}{c}\text { Emotional } \\
\text { Intelligence }\end{array}$ & $\begin{array}{c}\text { Resistance } \\
\text { to Change }\end{array}$ & $\begin{array}{c}\text { Organizational Learning } \\
\text { Capacity }\end{array}$ \\
\hline $\begin{array}{l}\text { Emotional Intelligence } \\
\begin{array}{l}\text { Resistance to Change } \\
\text { Organizational Learning }\end{array}\end{array}$ & 1 & 1 \\
Capacity & $-0.570^{* *}$ & $0.806^{*}$ & $0.760^{* *}$ \\
\hline$* \mathrm{P}$ value is less then $0.01 * * \mathrm{P}$ value is less then $0.05 * * * \mathrm{P}$ value is less then 0.10
\end{tabular}

Thereafter, we proceed with correlation analysis among the variables to find the association among the variables. There was a negative moderate association between Emotional Intelligence \& Resistance to Change which are -0.570 and it is significant at 0.05 level of significant. Moreover, the association between Emotional Intelligence \& Organizational Learning Capacity and Resistance to Change \& Organizational Learning Capacity are 0.806 and 0.760 which all significant at $0.01,0.05$ and 0.05 level of significant respectively.

\section{$5.5 \quad R^{2}$ value of Endogenous Variables}

\begin{tabular}{lcc} 
& $\mathbf{R}^{\mathbf{2}}$ Value & P-Value \\
\hline Resistance to Change & 0.63 & 0.021 \\
Emotional Intelligence & 0.38 & 0.0149 \\
Dependent Variable & Organizational Learning Capacity \\
\hline
\end{tabular}

Thereon, correlation analysis, When we analysis the variance among latent endogenous constructs that exogenous constructs through R2 value. The R2 value Resistance to Change is high and significant at 0.05 level of significant. Meanwhile, R2 value of Organizational Learning Capacity is moderate which has the value of 0.38 and significant at 0.05 level of significant.

\subsection{Johansen Co-Integration Test}

Johansen Co-Integration Test is used to analysis the long term and short term relationship between the variables.

\begin{tabular}{ccccc}
$\begin{array}{c}\text { Hypothesized } \\
\text { No. of CE(s) }\end{array}$ & Eigen Value & $\begin{array}{c}\text { Trace } \\
\text { Statistic }\end{array}$ & $\begin{array}{c}\mathbf{0 . 0 5} \\
\text { Critical Value }\end{array}$ & Prob.** \\
\hline None * & 0.181919 & 690.7904 & 69.81889 & 0.0001 \\
At most 1 * & 0.151640 & 483.1689 & 47.85613 & 0.0001 \\
At most 2 * & 0.116645 & 313.1280 & 29.79707 & 0.0001 \\
\hline
\end{tabular}


International Journal of Innovation, Creativity and Change. www.ijicc.net

Volume 15, Issue 6, 2021

Trace statistics define that there is three Co-Integration equations among the variables and which are highly significant at 0.01 level of significant. The analysis shows the long run relationship among the variables.

\begin{tabular}{ccccc}
$\begin{array}{c}\text { Hypothesized } \\
\text { No. of CE(s) }\end{array}$ & Eigen Value & $\begin{array}{c}\text { Max-Eigen } \\
\text { Statistic }\end{array}$ & $\begin{array}{c}\text { 0.05 } \\
\text { Critical Value }\end{array}$ & Prob.** \\
\hline None * & 0.181919 & 207.6215 & 33.87687 & 0.0001 \\
At most 1 * & 0.151640 & 170.0409 & 27.58434 & 0.0001 \\
At most 2 * & 0.116645 & 128.2450 & 21.13162 & 0.0001 \\
\hline
\end{tabular}

After Trace statistics, when we analysis the Max-Eigen Statistic, it defines three cointegration equations which are also significant at 0.01level of significant. Max-Eigen Statistic Seconded Trace statistics results that long run relationship exists among the variables.

5.7 Structural Relationships

\begin{tabular}{|c|c|c|c|c|}
\hline Path & $\begin{array}{c}\text { Path } \\
\text { Coefficient }\end{array}$ & Standard Error & T Statistics & P Value \\
\hline EI $\rightarrow$ RTC & -0.064412 & 0.035076 & -1.836320 & 0.0466 \\
\hline $\begin{array}{c}\mathrm{EI} \rightarrow \mathrm{RTC} \rightarrow \text { OLC } \\
\text { RTC }\end{array}$ & 0.108587 & 0.044510 & 2.439604 & 0.0149 \\
\hline$\stackrel{\mathrm{EI} \rightarrow \mathrm{OLC}}{ }$ & 0.268623 & 0.044107 & 6.090238 & 0.0000 \\
\hline
\end{tabular}

After Johansen Co-Integration Test, we analysis the path analysis to find out the coefficients of the variables. While analysis the association Emotional Intelligence with Resistance to Change, we find that the path coefficient value is -0.064412 and the $\mathrm{T}$ value is -1.836320 which is significant at 0.05 level of significant. The analysis described that 1 unit change in emotional intelligence will inversely change Resistance to Change by 0.0644 unit.

Furthermore, when we analysed Resistance to Change as mediating with Emotional Intelligence and Organizational Learning Capacity, we found that the path coefficient value is 0.108587 and the $\mathrm{T}$ value is 2.439604 which is significant at 5 percent level of difference. The analysis described that if 1 unit change occurs in Emotional Intelligence mediate with Resistance to Change will bring 0.1086 unit change in Organizational Learning Capacity.

Lastly, when we analysed Emotional Intelligence with Organizational Learning Capacity and moderate Resistance to Change, we found that the path coefficients value is 0.268623 and the T test value is 6.090238 which is highly significant at 0.01 level of significant. The analysis described that if Emotional Intelligence change by 1 unit will bring change 0.2686 unit in Organizational Learning Capacity by moderation of Resistance to Change. 
International Journal of Innovation, Creativity and Change. www.ijicc.net

Volume 15, Issue 6, 2021

\section{Conclusion}

The study analysed the relationship among Emotional Intelligence, Resistance to Change and Organizational Learning Capacity. The study was implemented on higher educational institutions of Pakistan. We get 392 responses from which 367 responses were completed in all respects and proceed for analysis. In correlation analysis we find strong positive association between Organizational Learning Capacity \& Emotional Intelligence and Organizational Learning Capacity \& Resistance to Change. Meanwhile, negative association between Emotional Intelligence \& Resistance to Change.

Max-Eigen Statistic and Trace statistics results in Johansen Co-Integration Test showed the long run relationship exists among the variables. The path coefficients values are -0.0644 for Emotional Intelligence with Resistance to Change, 0.1085 for Resistance to Change as mediating with Emotional Intelligence and Organizational Learning Capacity and 0.268623 for Emotional Intelligence with Organizational Learning Capacity and moderate by Resistance to Change which all are significant at 0.05 level of significant. 
International Journal of Innovation, Creativity and Change. www.ijicc.net

Volume 15, Issue 6, 2021

\section{REFERENCES}

Altındağ, E., \&Kösedağı, Y. (2015). The Relationship Between Emotional Intelligence of Managers, Innovative Corporate Culture and Employee Performance. Procedia - Social and Behavioral Sciences, 210, 270-282.

Aydin, B and Ceylan, A (2009), "Does organizational learning capacity (OLC) have impact on organizational effectiveness? Research analysis of the metal industry", Development and Learning in Organizations, 23 (3), 21 - 23.

Aydin, B., \&Ceylan, A. (2009b). The effect of spiritual leadership on organizational learning capacity. African Journal of Business Management, 3(May), 184-190.

Barney, J. (1991). Firm Resources and Sustained Competitive Advantage. Journal of Management, 17(1), 99-120.

Beal III, L., Stavros, J. M., \& Cole, M. L. (2013).Effect of psychological capital and resistance to change on organisational citizenship behaviour.SA Journal of Industrial Psychology, 39(2), 1-11.

Bellack JP. (1999). Emotional intelligence: a missing ingredient? Journal of Nursing Education 38(1): 3-4.

Bess, K. D., D. D. Perkins, et al. (2011). "Testing a measure of organizational learning capacity and readiness for transformational change in human services." Journal of prevention \& intervention in the community 39(1): 35-49.

Boyatzis, R. E., \&Saatcioglu, A. (2008).A 20-year view of trying to develop emotional, social and cognitive intelligence competencies in graduate management education.Journal of Management Development, 27(1), 92-108.

Cherniss, C. (2001). Emotional Intelligence and Organizational Effectiveness. The Emotionally Intelligent Workplace: How to Select for, Measure, and Improve Emotional Intelligence in Individuals, Groups, and Organizations. C. Cherniss and D. Goleman. San Francisco, CA, Jossey-Bass.

Coch, L. \& French, Jr. J.R.P. (1948), "Overcoming Resistance to Change", Human

Çömlek, O., Kitapçı, H., Çelik, V., \&Özşahin, M. (2012).The effects of organizational learning capacity on firm innovative performance.Procedia - Social and Behavioral Sciences, 41(6), 367-374.

Constantinescu, M., \&Alexandrache, C. (2014). Resistance to Changes in the Field of the Education.Procedia - Social and Behavioral Sciences, 137, 70-73.

De Geus, A.P. (1988).Planning as learning. Harvard Business Review, 88(2), 70-74.

Dent, E. B., \& Goldberg, S. G. (1999).Challenging 'resistance to change'. The Journal of Applied Behavioral Science, 35(1), 25-41. Evans, K., Hodkinson, P., Rainbird, H., \&Unwin, L. (2006).

Di Fabio, A., Bernaud, J.-L., \&Loarer, E. (2014).Emotional Intelligence or Personality in Resistance to Change?Empirical Results in an Italian Health Care Context.Journal of Employment Counseling, 51(4), 146-157. 
International Journal of Innovation, Creativity and Change. www.ijicc.net

Volume 15, Issue 6, 2021

Dimovshki, V. (1994). Organizational Learning and Competitive Advantage: A Theoretical and Empirical Analysis. Thesis Submission.

Doorewaard H, Benschop Y. (2003). HRM and organizational change: an emotional endeavor.Journal of Organizational Change and Management, 16(3), 272-286

Fatima, M. (2002). "Management of Quantum Change in Pakistan Organizations", The

Ford, J. D., Ford, L. W., \&D'Amelio, A. (2008). Resistance to Change: The Rest of the Story. Academy of Management Review, 33(2), 362-377.

Gardner L, Stough C. (2002).Examining the relationship between leadership and emotional intelligence in senior level managers. Leadership and Organization Development Journal 23(2), 68-78.

Ghosh, R., Shuck, B., \&Petrosko, J. (2012). Emotional intelligence and organizational learning in work teams. Journal of Management Development, 31(6), 603-619.

Goleman D. (1998). What makes a leader? Harvard Business Review Nov/Dec: 92-102.

Goleman, Deniel. (1995). Emotional Intelligence. New York, NY: Bantam.

Johnson PR, Indvik J. (1999). Organizational benefits of having emotionally intelligent managers and employees. Journal of Workplace Learning 11(3), 84-88.

Jordan, P. J. (2004). "Dealing with organisational change: Can emotional intelligence enhance organisational learning?" International Journal of Organisational Behaviour8(1), 456-471.

Jost, G., \& Bauer, M. W. (2003).Organizational learning by resistance. Institute of Social Psychology, London School of Economics Journal, 7(3), 1-17.

Judge, T. A., Thoresen, C. J., Pucik, V., \&Welbourne, T. M. (1999). Managerial coping with organizational change: A dispositional perspective. Journal of Applied Psychology, 84, 107-122.

Kanwal, E., Nawaz, W., Nisar, Q. A., \&Azeem, M. (2017). Does Organization Learning Capacity influence the Organization Effectiveness? Moderating Role of Absorptive Capacity, 1(7), 28-35.

Kazemi, M., Baghban, M., Degree, M., Branch, C., Azad, I., Fanoodi, S. Island, Q. (2013). A Study on Relationship between Emotional Intelligence and Organizational Learning. International Journal of Social Science Tomorrow, 2(9), 1-6.

Khan, I., Nawaz, A., Khan, M.S., (2013).Determining the Organizational Commitment of Academicians in Public Sector Universities of Developing Countries like Pakistan. International Journal of Academic Research in Accounting, Finance and Management Sciences, 3(1), 280-289.

Lawrence, P. R. (1954). How to deal with resistance to change. Harvard Business Review, 49-57.

Lazarus, R. S. (1991). Emotion and adaptation. New York, NY: Oxford University Press.

Malik, S. Z., \&Masood, S. (2015). Emotional Intelligence and Resistance to Change: Mediating role of Psychological Capital in Telecom Sector of Pakistan. Pakistan Journal of Commerce and Social Sciences, 9(2), 485-502. 
International Journal of Innovation, Creativity and Change. www.ijicc.net

Volume 15, Issue 6, 2021

Mayer, John D., \&Salovey, Peter. (1997). What is Emotional Intelligence? In P. \& D.J. Sluyter (Eds.), Emotional Development and Emotional Intelligence: New York: Basic Books.

Mayo, A. (2002). Forever change. Training Journal, (June), 40.

Mintzberg H., Waters J. (1985). Of strategies, deliberate and emergent. Strategic Management Journal, 6: 257-272.

Mir, G. M., \&Abbasi, A. S. (2012).Role of Emotional Intelligence in Developing Transformational Leadership in Higher Education Sector of Pakistan.Middle-East Journal of Scientific Research, 12(4), 563-571.

Mullings, B. (1999). Sides of the same coin?: Coping and resistance among Jamaican dataentry operators. Annals of the Association of American Geographers, 89(2), 290-322.

Nawab, S., Bhatti, K.K. (2011). Influence of Employee Compensation on Organizational Commitment and Job Satisfaction: A Case Study of Educational Sector of Pakistan. International Journal of Business and Social Science, 2(8), 25-32. Available at http://ijbssnet.com/journal/index/322

Neisser, U., G. Boodoo, T. J. Bouchard, Jr., A. W. Boykin, N. Brody, S. J. Ceci, D. F. Halpern, J. C. Loehlin, R. Perloff, R. J. Sternberg, and S. Urbina (1996). "Intelligence: Knowns and unknowns." American Psychologist, 51, 77-101.

Nevis, E., DiBella, A.J. and Gould, J.M. (1995), "Understanding organization learning systems", Sloan Management Review, 36(2), 73-85.

O'Brien, P. (Ed.) (2009). Accreditation: assuring and enhancing quality. New directions for higher education, 48(145), 1-6.

Ologbo, A. C., \&Chukwuekezie, C. S. (2013). Organizational Learning Capacity And Organizational Effectiveness: The Moderating role of Absorptive Capacity. In ISS \& $M L B, 774-779$.

Oreg, S. (2003). "Resistance to change: Developing an individual differences measure." Journal of Applied Psychology,88(4), 680-693.

Oreg, S. (2018). Resistance to Change and Performance: Toward a More Even-Handed View of Dispositional Resistance. Journal of Applied Behavioral Science, 54(1), 88-107.

Pardodel Val, M., \&Martínez Fuentes, C. (2003). Resistance to change: a literature review and empirical study. Management Decision, 41(2), 148-155.

Paul J. Davis(2017). "How HR can create competitive advantage for the firm: Applying the principles of resource-based theory". Human Resource Management International Digest, 25(2), 4-6.

Porter M. (1980). Competitive Strategy: Techniques for Analysing Industries and Competitors. Free Press: New York.

Porter, M. E. (1980). Competitive Strategy.New York: Free Press (Vol. 1).

Rafferty, A.E. \& Simons, R.H. 2006, "An Examination of the Antecedents of Readiness for Fine-Tuning and Corporate Transformation Changes", Journal of Business and Psychology, vol. 20, no. 3, pp. 325. 
Ramy, A. M., Akbar, A., Beydokhty, A., \&Jamshidy, L. (2014).Correlation between Emotional Intelligence and Creativity Factors. Intl. Res. J. Manag. Sci. International Research Journal of Management Sciences, 2(210), 301-304.

Relations, 1(4), 512-532

Saeidipour, B., Akbari, P., \& Amin MaratiFashi, M. (2012). Study the effect of emotional intelligence on organizational learning staff, Case study: Jihad Agriculture Organization of Isfahan. Management Science Letters, 2(7), 2501-2510.

Schein, E. H. (1986). 'Management development as a process of influence', in M. D. Richards (ed.) Readings in Management, Cincinnati, OH: South-Western, pp. 602-18.

Schutte N.S., Malouff, J.M., Bobik C, Coston, T.D.,Greeson, C, Jedlicka, C., Rhodes, E, Wendorf, G. (2001).Emotional intelligence and interpersonal relations. Journal of Social Psychology, 141(4), 523-536.

Schutte, N. S., Malouff, J. M., Hall, L. E., Haggerty, D. J., Cooper, J. T., Golden, C. J., \&Dornheim, L. (1998). Development and validation of a measure of emotional intelligence. Personality and Individual Differences, 25, 167-177.

Scott-Ladd, B., \& Chan, C. (2004). Emotional intelligence and participation in decisionmaking: strategies for promoting organizational learning and change. Strategic Change, 13(April), 95-105.

Sekaran, U. (2003). Research Methods for Business - A Skill Building Approach. New York: John Wiley and Sons, a. Inc.

Senge, Peter M. (2006). The Fifth Discipline: The Art and Practice of the Learning Organization. New York, Doubleday Business

Solomon CM. (1994). HR facilitates the learning organisation concept. Personnel Journal Nov: $56-66$.

Tallman, S., \&Fladmoe-lindquist, K. (2002).Internationalization, Globalization, and Capability-Based Strategy.California Management Review, 45(I), 116-135.

Teo, H., Wang, X., Wei, K., Sia, C. and Lee, M. (2006). 'Organizational learning capacity and attitude toward complex technological innovations: an empirical study", Journal of the American Society for Information Science and Technology, 57 (2), 264-279.

Thomas, J. B., Clark, S. M., \&Gioia, D. A.,(1993). Strategic sensemaking and organizational performance: Linkages among scanning, interpretation, actions, and outcomes. Academy of Management Journal, 36, 239-270.

Tsakalerou, M. (2016).Emotional intelligence competencies as antecedents of innovation. Electronic Journal of Knowledge Management, 14(4), 207-219.

Vakola, M., Tsaousis, I., \& Nikolaou, I. (2004). The role of emotional intelligence and personality variables on attitudes toward organizational change. Journal of Managerial Psychology, 19, 88-110.

Voola, R., J. Carlson, et al. (2004). "Emotional intelligence and competitive advantage: examining the relationship from a resource-based view " Strategic Change 13: 83-93.

Wall, P. D. (1979). On the relation of injury to pain, the John J Bonica lecture. Pain, 6, 253264. 
International Journal of Innovation, Creativity and Change. www.ijicc.net

Volume 15, Issue 6, 2021

Werther, W, B. (2003). Strategic change and leader- follower alignment.Organizational Dynamics, 32(1), 32-45.

Zander, A. (1950).Resistance to change - its analysis and prevention.Advanced Management Journal, 15, 9-11. Zuckerman,

Zhou, J., \& George, J. M. (2003).Awakening employeecreativity: The role of leader emotional intelligence. The Leadership Quarterly, 14(4-5), 545-568. 